\title{
Kierkegaard Americanus: \\ towards establishing a comparative analysis unit ${ }^{1}$
}

\author{
Abrahim H. Khan
}

DOI: 10.18355/XL.2018.11.04.01

\begin{abstract}
Søren Aabye Kierkegaard presents an extraordinary challenge not only to scholars in philosophy and theology but also other human sciences. The genius of his numerous writings has inspired many scholars and researchers down the decades, and the number of profound interpretations continues to grow, globally. This study focuses on the hermeneutical question his work provokes. It is a problem to understand the nuances of Kierkegaard's Danish language in the context of his life and culture; but our interpretations are also affected by our own times, culture and values. Several academic centres around the world are developing their own distinctive interpretive frameworks, and these might bias the interpretative effort of other scholars. My aim is to propose a comparative analysis unit or category. This is done by showing a correlation between the various historical, theological and cultural streams, especially in the Anglo-Saxon environment, in their interpretation of Kierkegaard's unique message in a move that identifies a dominant interpretation. The researchers who are closest to understanding his thought world are those who are willing to risk the undertaking the existential perception of their own time and its challenges in the context of their own authentic story in a Kierkegaardian way.
\end{abstract}

Key words: Kierkegaard, American exceptionalism, Puritans, hermeneutics, comparative analysis

\section{Introduction}

Among US scholars, Kierkegaard's thought and writings have intelligibility, unity, and coherence that may make him seem significantly different from how some others elsewhere in the world perceive him. To be sure, different interpretations and approaches abound, as Lee Barrett notes in his essay on the reception of Kierkegaard the USA (Barrett, 2009). However, a close study of the various approaches in Barrett's essay lends support to the idea of a dominant motif in the way Kierkegaard is interpreted, one whose frequent recurrence is suggestive of Kierkegaard Americanus.

Here I undertake to sketch this idea, Kierkegaard Americanus, that seems to be in wide circulation. It is either unconsciously disseminated by US scholars and/or embraced by others spending time in the US to work on Kierkegaard. A sketch of Kierkegaard Americanus, however rough it may be, is a first step towards establishing a comparative analysis unit. Such a unit may serve as a baseline by which to compare other approaches done outside the US, or to assess similarities and differences. In short, Kierkegaard Americanus is somewhat ideological, suited for the US psyche or readership and therefore gets embraced readily.

\footnotetext{
${ }^{1}$ An essay that opened the 3rd International Conference of the Central European Research Institute - Soren Kierkegaard, on February 20-22, 2018, at Constantine the Philosopher University, Nitra, Slovakia. The theme of the conference was on. Kierkegaard in a Central European Context.
} 


\section{Cultural horizons}

Implications of ideology and making available a comparative analysis unit are in line with recent findings (Uhlmann, Poehlman, Nosek, 2012 and 2012a) in the area of social psychology and cognition. Thinking is culture centered, where culture is understood by social scientists as "the unwritten rules of the social game, or "collective programming" (Hofstede, Hofstede, Minkov, 2010: 5f). Hofstede (2017) constructed a country comparison tool. That is, a model of a national culture consisting of six dimensions or indices by which to compare national cultures. That is, an individual's intuitive core values and basic cognitive processes are shaped by culture and environment and vary from one culture to another. Accordingly, to understand adequately the software-like mind of the literary interpreter, the putative mental processes by which automatic associations are made with respect to social targets and core values, one has to consider also the interpreter's cultural context and environment. Note, however, that culture as defined by Hosted for such associative studies is "the collective mental programming of the human mind which distinguishes one group of people from another" (Hofstede, Hofstede, Minkov, 2010: 228). By programming is meant "patterns of thinking which are reflected in the meaning people attached to various aspects of life and which become crystalized in the institutions of a society." (Ibid.) Further, it does not mean that everyone in a particular country behaves or is programmed the same way.

For example, a South Asian interpreting Kierkegaard is likely to have a different perspective or understanding. Not just on Kierkegaard, but also interpretations in the human sciences. Such would also be the case with an Eastern or Central European scholar. He or she would likely have a distinct set of primed concepts determining the automatic associations that unconsciously come into play, as well as a different range of hermeneutical options, with preference tendencies. Even within a continent or state, variations in interpretation are quite likely and are accounted for by the environment and cultural context. These are reasons for undertaking comparison for what has been missed, or mistaken as similar, or even for leveling out biases and having a baseline. To move on to Kierkegaard Americanus, as both idea and interpretative category, it has a cultural linkage or mental programming to the notion of American exceptionalism, which may explain its wide circulation. More specifically, it has an affinity to cherished values associated with a Puritan community or way of life. In that respect, Kierkegaard Americanus is essentially an ethico-religious author whose primary concern is with engaging religious concepts in shaping how we live and think.

\section{Political horizons}

To elucidate further, American exceptionalism has to it a moral face or dimension, implying the goodness of America: its values, benefits, and supremacy as a world power. The phrase reflects a usage or meaning of the term "exception," as "to set apart from the rule or expectation." This sense or use of the phrase reverberates in US presidential candidate political rhetoric in recent decades. It became a rallying cry for political agendas to deal with polarized economic and military situations in the world or with geopolitical turmoil. Not all subscribed to the US view of itself as being exceptional; for blindness to its own history, according to Hodgson (2009) has led to a complacent nationalism and dangerous foreign policy. Tyrrell (2016) in his article identifies its reference by Kennedy, Nixon, Regan, Clinton, Romney, and more recently by presidents Bush and Obama to the idea of a City on a Hill, a metaphor associated with the idea of a supremacy in a Global sense because of "the last, best hope of mankind" (Gingrich, 2011: 8). The phrase 'American exceptionalism carried'

XLinguae, Volume 11 Issue 4, October 2018, ISSN 1337-8384, eISSN 2453-711X 
forward the idea of the US as a model society: the bearer of freedom and liberty, morally superior to something called "Europe" (Ibid.: 11).

The idea of the US as a model society to be emulated by the world may have been incipient in De Tocqueville's 1830s travelogue and study of US institutions and moral behavior. In it, he refers to a principle of equality of the development that is unstoppable and is seen as a Providential fact (De Tocqueville, 2002: 5). For this French political scientist and historian saw the US as a model of a democratic society that needed to be understood and a country as the harbinger of a future that included the democratization of Europe. The expression gained wide application as an explanatory category: from accounting for a radicalized working class, to becoming associated with capitalism, to a way of life that is unique and desired or envied by others outside the US, to cherished values associated with a Puritan view of community, and to the emergence of the US as a military and economic world power acting outside the norms of other liberal democratic societies.

\section{Sociological horizons}

Michael Ignatieff (2005: 3-4) offers four types of explanations of American exceptionalism: realist, cultural, institutional, and political. Additional types are identified by Harold Hongju Koh, who noted that the exceptionalism is with respect to US global leadership and activism (2003: 1487): "To this day, the United States remains the only superpower capable, and at times willing, to commit real resources and make real sacrifices to build, sustain, and drive an international system committed to international law, democracy, and the promotion of human rights." It is this leadership role that enables or advances international circulation of Kierkegaard Americanus.

Though of different types, American exceptionalism has a conceptual tie to spreading democracy, freedom, and culture as the manifest destiny of the US. Seymour Martin Lipset (1997), a Stanford University political sociologist, explains its sense of exception this way: the US as the leader of the free world, and as chief victor in the Second World War over "totalitarian" Germany, and by far the world's most prosperous economy, seemed in all these ways an exceptional nation. He held fast to the view that the U.S. was not subject to the historical norms of all other nations, until his death in 2006. This view of moral superiority has a resonance with the messianic or missionary convictions underscored by Alexis de Tocqueville's account of modern democracy as God's will (De Tocqueville, 2002: 5-7, 53-55). His analysis notes very clearly Christian influences through Puritanism on notions of freedom and equality.

To be clear, aspects of American moral exceptionalism are associated with values rooted in a New England Puritan worldview and ideals (Uhlmann, Poehlman, Tannenbaum, Bargh, 2011). The ideals remain deeply lodged in the contemporary American psyche, forming part of US national identity and serve to explain how Kierkegaard Americanus came to be institutionalized and embraced widely. For the fit between an ethico-religious Kierkegaard and the American psyche and character was just right.

\section{Puritan horizons}

To expand further, the new Puritan community of New England would be paradise on earth, serving as model or guide for the rest of the world. The idea of a moral guide was introduced by the devout Puritan leader John Winthrop and first governor of Massachusetts Bay colony. In his 1630 sermon "A Model of Christian Charity" (Winthrop, 2009), he declared to his listeners that they had a pact with God to create a holy community, urging them to consider that they "shall be as a city upon a hill," and that the eyes "of all people are upon" them. The Pilgrims too saw "themselves as participating with God in creating the millenarian kingdom of God on earth,' and upholding education, fair wages, healthy souls and bodies would result in the 
millennium coming to the USA (Woodward, 1999: 68-73). Altogether, the Puritan way of seeing the world included hard work as a religious duty, the importance of self-examination and self-discipline with respect to salvation, Bible study, and understanding themselves as a group set apart from organized religion to create a new Jerusalem, and it continues to influences contemporary American behaviors and judgments in the domains of individualism and traditionalism.

The value system of this late $17^{\text {th }}$-century religious community is still lodged in the modern American psyche, according to the findings of social psychologist Eric Uhlmann (2011) and his research team. Its influence is evident in the strand of American exceptionalism that involves a desire for moral leadership connected with a strong messianic vision. That vision includes spreading globally US democratic values, freedom and social justice at all costs as a way of leading to the new Jerusalem. Its correlated piety and religious fervor meshed with that of the Great Awakening or Evangelical Revival movement that continued into the $18^{\text {th }}$ century and would reach the settled frontiers or mid-west America. The spectrum of externalizing and systematizing the Augustinian strand of pietism "of intensified religious and moral resolutions" through the different colonies of settlers or commonwealth on the Atlantic seaboard, is perhaps captured by the expression "the New England Way" (Ahlstrom, 2004: 274-279). This particular Way, for US historian Sydney Ahlstrom (2004: 149), "rested on the conviction that the entire commonwealth was intended to be as 'faithfully under God' as it could possibly be."

Certain theological ideas in the Puritan-Protestant value system had priority: Providence, the individual in relation to or before God, inward self-examination, reading scripture regularly, biblical passages to start a sermon in a plain and simple way, and faith as the key to salvation (PBS, 2010). Inwardly incorporating those in one's life produces a certain type of person for whom economic success is possible and taken as a sign of grace: for example, hard work and self-discipline were considered as part of religious duty. Presumably, the theological ideas too are etched in the American religious psyche and may be an explanation of why the picture of Kierkegaard as an ethico-religious thinker is the dominant one among American scholars. Clearly more than a set of religious beliefs, New England Puritanism combines life styles with values that have to be lived out.

No wonder then, a theological setting of the 1880s is where Kierkegaard's thought makes its institutional debut: in the curriculum of the Norwegian-Danish Theological School, Evanston, Illinois. This institution, of a revivalist-pietistic-Methodist Church tradition was established to educate ministers for Scandinavian churches in the Midwest (Lawson, 1981: 181) and also the pietism influences of the DanishNorwegian immigrant in connection with Kierkegaard's attack upon the State Church is noticeable (Halle, 1979: 87). It was followed by a burst of energy to translate into English Kierkegaard texts. Which titles would be given priority? Back east, in 1935, the first to get translated was a set of edifying discourses with the title Purity of Heart is to Will One Thing done by a professor at Haverford College, a Quaker-founded institution outside Philadelphia, and published in1938. Unmistakably ethico-religious, the discourses must have been considered to be closest to a Puritan-Protestant mindset. Other ethico-religious translations followed closely: The Point of View of My work as an Author (1939), a text in which Kierkegaard declares that he saw himself as a religious author; another was Walter Lowrie's biography of Kierkegaard (1938) presenting him as a Christian writer. Two years later (1941) appeared translations for Self-Examination, and Thoughts on Crucial Situations. Ethicoreligious, the translated titles and perceptions of Kierkegaard that they convey seem intended to blend with a Puritan-Protestant evangelical mindset.

\section{Swenson-Holmer horizons}

XLinguae, Volume 11 Issue 4, October 2018, ISSN 1337-8384, eISSN 2453-711X 
By 1914, the institutionalizing of an ethico-religious Kierkegaard gained an impetus from David F. Swenson, of Swedish evangelical pietistic tradition, and a University of Minnesota philosopher. Swenson belong to the Swedish Evangelical Mission Covenant Church and was raised by a "deeply religious mother" (Anderson, 2001: 303-306) and believed himself to be following in the footsteps of Socrates in confrontations with respect to matters of principles and fairness. He would later translate Philosophical Fragments (1936), having lectured and published on Kierkegaard. His interpretative strategy stresses the ethical understood as having to make a choice with respect to the shape of your life and entails holding together passion and reason. One of his essays has this to say (Swenson, 2000: 111): "In Kierkegaard, we have a thinker who completely reverses the Cartesian distribution of emphasis: he reflects where Descartes accepts and accepts where Descartes reflects." He characterized Kierkegaard as a Danish Socrates, a subjective thinker employing the category of indirect communication, with respect to ethico-religious reality or existence (2000: 36-67). To quote Swenson (2000: 156), "Every deeper ethicoreligious conviction ... is an expression of the inner depths of the personality." Through Swenson, Kierkegaard gradually gained among preachers and teachers of Danish background an appreciative reception (Lawson, 1981: 184).

This incipient idea of ethico-religious Kierkegaard as an interpretative strategy acquired definitiveness and gained an extensive reach through the influential scholar Paul L. Holmer. A student of Swenson and from a Swedish Lutheran pietism tradition, Holmer became a professor of philosophy and theology at Yale Divinity School. He had been developing themes broached by Swenson. His essays gave depth to the characterization of Kierkegaard as a philosopher concerned with the notions of subjectivity as Truth and indirect communication, as delineated by two essays. One in 1955 has the title "On Understanding Kierkegaard" (Holmer, 1962) and the other, appearing two years later, has for its title "Soren Kierkegaard: Faith in a Tragic World" (Holmer, 1957). Their delineation of Kierkegaard encompassed the theory of stages, the theory of communication, the notion of presenting possible life styles to evoke from the reader a response to make them actual for him or herself. He connected them to the idea of the life of passion, or inner cosmos, as having to be ordered as well. He augmented that picture by drawing on C.S. Lewis, Wittgenstein, and ordinary language analysis philosophical tradition to explicate ethico-religious concepts in Kierkegaard's thought, to clarify their grammar. The assigned title to a volume of his collected papers, edited by two former students and later distinguished US Kierkegaard scholars, David Gouwens and Lee Barrett, is brief and pointed: $O n$ Kierkegaard and Truth (Holmer, 2012). Another former student of his, Stanley Hauerwas whom Time Magazine in 2001 named as America's best theologian, ended his foreword to the edited volume with these words (Holmer, 2012: xiif): "this is a book that forces us to read Kierkegaard as if our lives were at stake. In the process, I think you will find that the fear of God makes joy possible." As with Holmer, so too with Hauerwas: Kierkegaard is a kind of philosopher seeking to provoke the reader to think about the quality of his/her own life.

Holmer produced, in effect, a thick description of the ethico-religious Kierkegaard by explicating how Kierkegaard is doing philosophy. He showed that Kierkegaard is engaged in clarifying how basic life-shaping concepts come to have meaning for one's own life: getting the grammar of such concepts correct; seeing theology as the grammar of the heart. This meant distinguishing between knowing and doing the truth, between the "how" and the "what" as part of clarifying doctrinal or Christian concepts to enable subjective appropriation of them. Holmer's characterization of Kierkegaard meshed with a strand of pietism according to an anecdotal report "What I learned from Paul Holmer." by another former student Arvid Adell (2014) who became a university professor. 
Aiding receptivity of the Swenson-Holmer Kierkegaard was an emerging current of thought shaping American Neo-orthodoxy of the '20s and ' 30 s. I am referring to the existential current underscoring a sense of urgency and demand for moral as well as intellectual humility (Ahlstrom, 2004: 937-945). This underscoring meant for Neoorthodox theologians the primacy of knowing the "how" one finds oneself in the world, of human predicament or estrangement with respect to existing as subject, rather than the "what" of specific theological doctrines or of existing as an object. While that primacy accords well with the revival of evangelical exegesis it did not detract from the dialectical temper associated with the development of Kierkegaard themes such as paradox/incarnation, ethics of love, indirect communication or theory of stages. They aided the response to liberal theology in America, thereby contributing to the dominance of the ethico-religious Kierkegaard.

\section{AAR. radius operandi}

From Paul Holmer's former students, the ethico-religious Kierkegaard received a new impetus to become a dominant motif on the US academic scene. Many of his students have distinguished themselves as Kierkegaard scholars through publications and/or contributions to institutionalizing Kierkegaard in the American Academy of Religion. This latter, known as the AAR, focuses on the academic study of religion, has a membership of approximately 10,000 and holds at its annual meetings over 1000 events. One of its program units is Kierkegaard, Religion, and Culture which holds three or four sessions at the annual meeting (AAR, 2018). To the names already mentioned, we may add Sylvia Perkins (previously Utterback/Walsh), Robert Roberts, Stephen Evans, Andrew Burgess, David Cain, Bill Cahoy, and Don Sailers, to name a few. Through publications, thesis supervisions and lectures at home and abroad, they contributed to disseminating and making Kierkegaard dominant as an ethico-religious author, hence the emergence of Kierkegaard Americanus.

Its emergence is no doubt aided in different ways by other distinguished and influential Kierkegaard Studies scholars in the US. They include names such as Howard and Edna Hong who replicated Kierkegaard's Library at St. Olaf College in Minnesota, Robert L. Perkins as editor of the International Kierkegaard Commentary Series, Merold Westphal, Bruce H. Kirmmse, Gordon Marino, Ed Mooney, M. Jamie Ferreira, and Mark C. Taylor. Each has their own reading or emphasis but always presupposes the ethico-religious throughout the literary production or at the least the rudiments of Kierkegaard Americanus.

Different interpretations or approaches to Kierkegaard prevail among scholars in and outside the US, no doubt. He is an irrationalist or a fideist, or ant-intellectualist to some. One Marxist scholar (Bykhovskii, 1976) considers the apolitical character of his thought to be anti-political, and takes his subjectivity and return to Christian Utopia as ethics which has nothing in common with the ethics of social existence. Still some other see his authorship as the writings of a conflicted individual: a guilt-ridden personality vis-a-vis a father's indiscretion and/or a broken engagement. Yet another line of interpretation is that of an oppositional figure, one in a confrontation with the Church and the Corsair, and with ambivalence to Christianity. Then, there is Kierkegaard as a falsifier of history taken by Danish scholars. They, unlike proponents of Kierkegaard Americanus, put no stock on his account in the Point of View of My Work as an Author." Still, some other interpretations depict him in relation to currents in European philosophy: Kant, Hegel, or the Romantic Movement. Perhaps the most damaging to the Swenson-Holmer interpretative strategy is the accusation by the Danish scholars Joakim Garff and Henning Fenger. According to Garff (1991: 40-41) Kierkegaard introduced and arranged documentation to make himself seen as a religious author. Both Garff (2005: 550-554) and Fenger (1980: 131 ) in his first chapter entitled "Kierkegaard as a Falsifier of History" argue that

XLinguae, Volume 11 Issue 4, October 2018, ISSN 1337-8384, eISSN 2453-711X 
Kierkegaard falsifies documentation so as to claim his whole authorship is in the service of Christianity. But none of these interpretations has so far burgeoned into a dominant strand in the scholarship as is the case with Kierkegaard Americanus.

\section{Conclusions}

The sketch of Kierkegaard Americanus holds out the possibility for a comparative analysis unit or paradigm. By this, I mean a distinctive interpretative strategy with expositors, critics, and investigative tradition to constitute a modern research program. Its rudiments include seeing Kierkegaard as an ethico-religious thinker, engaged in clarifying the conceptual grammar of faith. And further, that Kierkegaard's philosophical strategy involves the use of indirect communication to move his reader to choose any life style from the variety his authorship presents. This analytic element is prominent, having been forged in the crucible of a Puritan, pietistic, evangelical, messianic cultural tradition that is part of the collective programming with respect to pride in US national identity. It is one that is coherent with American moral exceptionalism.

Taken as a baseline still in the making, the proposed unit is a tool for comparing interpretative perspectives coming from Kierkegaard commentators and expositors working outside an American cultural setting. It can then be ascertained whether the reading of Kierkegaard is simply an annexation of a particular US view of Kierkegaard or one that arises from engaging with one's own cultural and socialpolitical realities. Thinking processes and core values are shaped by culture and environment. Kierkegaard Americanus flows out of a psyche shaped by a strand of pietism associated with US national character, or the goodness of America: its values, benefits, and supremacy, hence American exceptionalism, collective programming.

The goodness spills over as well to scholarly undertakings. Kierkegaard Americanus is tied up with presentation and material production. For example, how it is to be presented for dissemination, what publication format or style is acceptable as scholarly, who determines its direction or research program, and who gets invited for keynote addresses or to serve on advisory or editorial boards. As does acceptable scholarship elsewhere, Kierkegaard Americanus has a hegemonic aspect, is the gold standard, offered as a benefit.

For Kierkegaard to have relevance for different life situations, for one's own cultural context and values, would mean reflecting also on the framework options to guide analysis and thus being mindful of not overlooking the presuppositions of one's own cultural context, instead of engaging in mimesis. More concretely put, heeding also what it means to be a Central European, South Asian, Chinese, or Latin American, as the case may be in settling on an interpretative strategy. Analogously and as a reminder, Kierkegaard himself eschewed the bright light of German idealism, objecting to how it had volatilized Christian concepts, and spoke of having a Danish philosophy.

To conclude, Kierkegaard Americanus as presented here may be just a surface reading in the world of Kierkegaard scholarship. As such, more work is required to test the hypothesis that it is a dominant and disseminated picture of Kierkegaard. Thus, it is a start towards a comparative undertaking that may produce refinement or lead to being more heedful of one's own scholarship and its presuppositions. At best, it may be outline of an incipient idea to develop further into a project for research funding.

\section{Bibliographic references}

AAR. 2018. American Academy of Religion: Annual Meeting. Available online [February, 5, 2018]: https://www.aarweb.org/annual-meeting

ADELL, A. 2004. What I Learned from Paul Holmer: An Anecdotal Report. In: Pietisten, vol. XIX, no. 2. Minneapolis: Pietisten, Inc. Available online [February, 1, 2018]: http://www.pietisten.org/xix/2/holmer.html 
AHLSTROM, S. E. 2004. A Religious History of the American People. New Haven and London: Yale University Press. ISBN 9780300100129.

ANDERSON, P. J. 2001. David F. Swenson, Evolution and Public Education in Minnesota. In: Swedes in the Twin Cities: Immigrant Life and Minnesota's Urban Frontier. Eds.: P. J. Anderson and D. Blanck. St. Paul: Minnesota Historical Society, pp. 302-316. ISBN 9780873513999.

BARRETT, L. C. 2009. The USA: From Neo-Orthodoxy to Plurality. In: Kierkegaard International Reception: The Near East, Asia, Australia, and the Americas, Tome III, edited by Jon Stewart. Burlington, Vermont: Ashgate, pp. 229-268. ISBN 9781138257320 .

BYKHOVSKII, B. 1976. Kierkegaard. Amsterdam: B. R. Grüner Publishing Company. ISBN 9789060320709.

DE TOCQUEVILLE, A. 2002. Democracy in America. Translated and edited by D.

Winthrop and H. C. Mansfield. Chicago: Chicago University Press. ISBN 9780226805368 .

FENGER, H. 1980. Kierkegaard, the Myths and Their Origins: Studies in the Kierkegaardian Papers and Letters. New Haven: Yale University Press. ISBN 9780300024623.

GARFF, J. 1991. The Eyes of Argus: The Point of View and Points of View with Respect to Kierkegaard's 'Activity as an Author'. In: Kierkegaardiana 15. Eds.: Joakim Garff, Eberhard Harbsmeier, Helge Hultberg, Poul Lübcke. Copenhagen: C. A. Reitzel Forlag, pp. 29-54. ISSN 0075-6032.

GARFF, J. 2005. Søren Kierkegaard: A Biography. Princeton: Princeton University Press. ISBN 9780691091655.

GINGRICH, N. 2011. Nation Like no Other: Why American Exceptionalism Matters.

Washington, D. C.: Regnery Publishing, Inc. ISBN 978-1596982710.

HALE, F. 1979. Norwegians, Danes, and the Origins of the Evangelical Free Tradition. In: Norwegian-American Studies, Vol. 28, pp. 82-108. ASIN: B003KDWA9S.

HODGSON, G. 2009. The Myth of American Exceptionalism. Michigan: Sheridan Books. ISBN 9780300164190.

HOFSTEDE, G. - HOFSTEDE, G. J. - MINKOV, M. 2010. Cultures and Organizations: Software of the Mind, Intercultural Cooperation and its Importance for Survival, $3^{\text {rd }}$ edition. New York: McGraw Hill. ISBN 9780071664189.

HOFSTEDE, G. National Culture. 2017. Available online [January, 28, 2018]: https://www.hofstede-insights.com/models/

HOLMER, P. L.1957. Søren Kierkegaard: Faith in a Tragic World. In: The Tragic Vision and The Christian Faith. Ed.: Nathan A. Scott, Jr. New York: Association Press, pp. 174-188. ASIN B000O2COX0.

HOLMER, P. L. 1962. On Understanding Kierkegaard. In: A Kierkegaard Critique: An International Selection of Essays Interpreting Kierkegaard, eds.: Howard A. Johnson and Niels Thulstrup. Chicago: Henry Regnery Company, pp. 40-53. ASIN B0007DFFZ0.

HOLMER, P. L. 2012. On Kierkegaard and Truth. Eds.: David L. Gouwens and Lee C. Barrett III. Cambridge: James Clarke \& Co. ISBN 9780227680049.

IGNATIEFF, M. 2005. American Exceptionalism and Human Rights. Princeton: Princeton University Press, ISBN 9780691116488.

$\mathrm{KOH}$, H. H. 2003. On American Exceptionalism. In: Stanford Law Review, Vol.55:1479, pp. 1480-1527. ISSN 0038-9765. Available online [February, 5, 2018]: http://digitalcommons.law.yale.edu/cgi/viewcontent.cgi?article $=2737 \&$ context $=$ fss_pa pers

XLinguae, Volume 11 Issue 4, October 2018, ISSN 1337-8384, eISSN 2453-711X 
LAWSON, L. A. 1981. Small Talk on the 'Melancholy Dane' in America. In: The Legacy of Interpretation of Kierkegaard. Eds.: Niels Thulstrup and Maria M. Thulstrup. Copenhagen: C. A. Reitzels, pp. 178-197. ISBN 9788774213154.

LIPSET, S. M. 1997. American Exceptionalism: A Double-Edged Sword. New York: W. W. Norton \& Company. ISBN 9780393316148.

PBS. 2010. People \& Ideas: The Puritans. Online [January, 23, 2018]: http://www.pbs.org/godinamerica/people/puritans.html

SWENSON, D. F. 2000. Something About Kierkegaard. Macon: Mercer University Press. ISBN 9780865548602.

TYRREL, I. 2016. What, exactly, is "American exceptionalism"? Available online [January, 24, 2018]: http://theweek.com/articles/654508/what-exactly-americanexceptionalism

UHLMANN, E. L. - POEHLMAN, T. A. - NOSEK, B. A. 2012. Automatic Associations: Personal Attitudes or Cultural Knowledge. In: Ideology, Psychology, and Law, edited by Jon Hanson. Oxford: Oxford University Press, pp. 228-230. ISBN 9780199737512.

UHLMANN, E. L. - POEHLMAN, T. A. - NOSEK, B. A. 2012a. Running Head: Person and Culture. Available online [Feb, 5, 2018]:

http://www.socialjudgments.com/docs/Uhlmann_Poehlman_Nosek_2012.pdf

UHLMANN, E. L. - POEHLMAN, T. A. - TĀNNENBAUMM, D. - BARGH, J. A. 2011. Implicit Puritanism in American moral cognition. In: Journal of Experimental Social Psychology, vol. 47, n. 2, pp. 312-320. ISSN 0022-1031.

WINTHROP, J. 2009. A Model of Christian Charity (1630). Kindle Edition, Evergreen Review, Inc. ASIN B004HW7KM8.

WOODWARD, K. L. 2005. The Way the World Ends. In: Newsweek (November, 1, 1999. Available online [January, 24, 2018]: http://www.newsweek.com/way-worldends- 167602

Words: 4841

Characters: 32353 (17,97 standard pages)

prof. B.S., B.D., M.A., Ph.D., Dr.h.c., Abrahim H. Khan

Trinity College

University of Toronto

Larkin Building, Room 313, 6 Hoskin Avenue, Toronto, ON M5S 1H8

Canada

khanah@chass.utoronto.ca 